\title{
Religious tolerance and intolerance: 'Engravings' on the soul
}

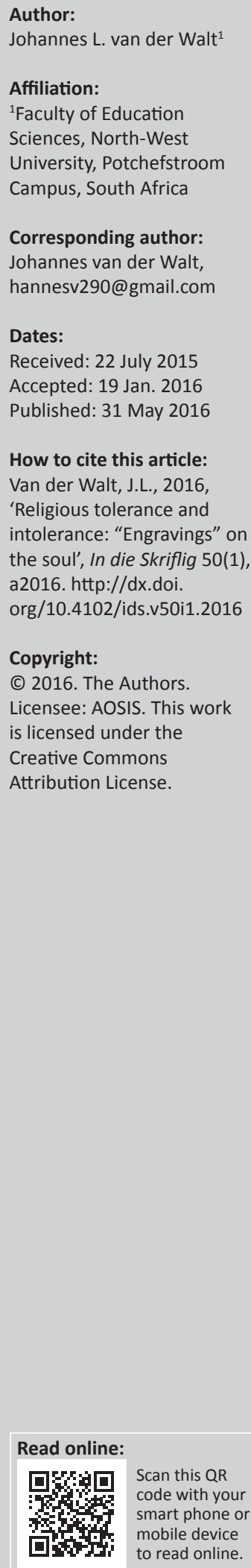

The recent violent anti-social acts by individuals and groups who feel deeply committed to some or other religious ideal have underscored the importance of the inculcation of religious tolerance in young children for the sake of peaceful coexistence in increasingly diverse and pluralistic communities. The key to such inculcation is education in the most positive sense of the word, i.e. as nurturing, guiding and equipping. Research has shown that some young people are being subjected to a form of negative pedagogy or anti-pedagogy that shapes them to be religiously intolerant. The purpose of this article is to show how education in the most positive sense of the word could be employed to make such etchings on the souls (personalities) of young people that would shape them to become cultured and religiously tolerant persons. They could become people with integrity, equipped with life-maps helping them to live peacefully in increasingly diverse and pluralistic societies, able and willing to contribute to their own well-being and also to that of all other people.

\section{The problem under scrutiny}

Religious tolerance or intolerance arguably must have begun with an individual who subsequently influenced others to be similarly tolerant or intolerant, thereby forming a religiously tolerant or intolerant group. From then on, groups might have influenced, inspired, convinced or coerced other individuals to be either tolerant or intolerant of others, their thinking and behaviour. In this manner, religious tolerance or intolerance came to be perpetuated: groups or communities influencing individuals to be(come) tolerant or intolerant; conversely, individuals creating groups or communities characterised by attitudes of religious tolerance or intolerance. We today realise that religious tolerance and intolerance flow from individuals' perceptions, thoughts and attitudes, from their 'self-talk' (cf. Thurman 1999:231 regarding 'self-talk'). It is therefore easier to understand religious tolerance and intolerance from an individual and personal perspective than from a group perspective. Recent incidences associated with religious intolerance in many parts of the world (see below) demand that we gain an understanding of what religious tolerance and intolerance actually entails.

The word person denotes an individual human being (Sinclair 1999:1103), and is derived from the Latin persona, meaning a mask. According to Simpson (1968:442), persona originally referred to the mask worn by actors in Greek and Roman drama, particularly to the role, part, character or person played in the drama. It later acquired the figurative meaning of the part or role that someone plays in life (e.g. as a tolerant or intolerant individual), and later on to also mean an individual's personality, individuality and character. The word personality was later used to refer to the sum total of all the behavioural and mental characteristics on the grounds of which a person is recognised as unique; also in terms of how the person displays tolerance or intolerance of others who are religiously different. Personality refers to the distinctive character of a person that makes him or her socially attractive or unattractive (Sinclair 1999:1104) - also in terms of being religiously tolerant or intolerant.

Two words have so far been used repeatedly in connection with person, namely individuality and character. Individuality denotes the distinctive or unique personality or character of a person, including the qualities that distinguish one person from another, also in terms of being religiously tolerant or intolerant (Sinclair 1999:733). Character, on the other hand, denotes the combination of traits and qualities that distinguish the individual nature of a person. The word is derived from the Latin 'distinguishing mark', from the Greek kharakter, an engraver's tool or stamping tool. In the fourteenth century the word carecter was used for a symbol marked or branded on the body. Its later use came to mean 'symbol or imprint on the soul'. The extended meaning by metaphor to 'a defining quality' is particularly relevant in the context of religious tolerance or intolerance. Tolerance and intolerance can indeed be seen as a defining quality of someone in his or her 
relationship with others with whom they do not see eye to eye. The meaning of character as the 'sum of qualities that define a person' is only from the 1640s (Online Etymological Dictionary 2015).

The question dealt with in the research leading to this article was: How does a person acquire the defining quality of being religiously tolerant or intolerant towards others of different religious persuasion? Put differently, how does a person's soul become 'engraved' with the character of being religiously tolerant or intolerant?

\section{Engravings on the soul}

Character as engraving on the soul has the metaphorical meaning of a 'symbol or an imprint on the soul'. According to Harper (2001-2015), the word soul denotes a substantial entity believed to be that in each person which lives, feels, perceives, thinks and wills. The Old English sawol referred to the spiritual and emotional part of a person, to animate existence, life, a living being, derived from the ProtoGermanic saiwolo. Originally this word meant something like 'coming from or belonging to the sea' because that was supposed to be the stopping place of the soul before birth and after death. A semantic connection between 'person' or 'individual' and 'soul' was made after the fourteenth century when soul came to be used as a synonym for person, individual and human being (as in 'every living soul').

There is a connection between this last meaning of 'soul' and the biblical view of 'soul'. The two most common renderings of the Hebrew nephesh in English are soul and life. Nephesh in the Old Testament refers to 'the life principle' or 'living being', never to 'the immortal soul' (cf. Gn 1:20, 21, 24; 2:7). Frequently nephesh also designates the individual (Lv 17:10; 23:30). The Revised Standard Version of the Bible reflects nephesh as personal or reflexive pronoun with translations such as 'being', 'self' and 'I or me'. Clearly, in the Old Testament a mortal is a living soul rather than having a soul. The term soul describes a human being from the perspective of the choices he or she makes in Deuteronomy 18:6, and as a thinking, inquiring being in Ecclesiastes 7:28 (Towner 2015). Hebrew thought sees a soul as a unified human being, one that is profoundly complex, a psychosocial being (Schultz 2015).

The counterpart of nephesh in the New Testament is psyche. The meanings of psyche are similar to those of nephesh: it often designates life (Jh 13:37; Ac 15:26; Rm 16:4; Phlp 2:30). It can also designate person (Ac 2:41; 27:37). It also serves as the reflexive pronoun designating the self or myself (Lk 12:19; 2 Cor 1:23; 1 Th 2:8). In some passages, psyche stands in contrast to the body, and there it seems to refer to an immortal part of man (Mt 10:28). Schultz (2015) correctly concludes: 'While Scripture generally addresses humans as unitary beings, there are passages that seem to allow divisibility within unity'.
Other words that come to mind in this context are heart and mind or reason. According to the Bible, the heart is the centre not only of spiritual activity but of all ( $\operatorname{Pr} 4: 23)$. Heart and soul are often used interchangeably (Dt 6:5; 26:16; Mt 22:37), but this is not generally the case. Generally speaking, the Bible sees the heart as the home of the personal life (cf. $1 \mathrm{Ki} \mathrm{3:12}$; Waltke 2015). In the Old Testament, the heart is sometimes understood as the mind. Heart, in a figurative sense, refers to the inner person (1 Ki 3:12; 2 Chr 12:14; Neh 4:6; Pr 16:23). Decisions of a moral nature take place in the heart (Gn 20:5; Job 11:13). Heart thus serves as a reference to the person as a thinking, perceiving and willing being, bringing together the ideas of knowledge, understanding and will. The meaning of heart ties in with soul which can also refer to the intellectual or mental dimension of life (Dt 6:5; 1 Chr 22:19; 28:9).

Based on the meanings and uses of the various words, it is not unreasonable to conclude that religious tolerance or intolerance can be regarded as engravings, symbols, characters made on the soul of individuals as human beings. Put differently, tolerance or intolerance as an attitude, a lifeview and behaviour is a trait that can be instilled to become a characteristic feature of a person. The question then becomes: Who makes such imprints on the souls of young people, and how is this done? We have in recent times observed many instances of religiously intolerant behaviour and also many instances of human beings bearing the engravings of religious intolerance on their souls. Mention need only be made of the Boston killings, the Norway attacks, Christian-right-wing attacks in South Africa (Potgieter 2014:68-71), the Paris attacks, the Cairo killings, the atrocities perpetrated by Boko Haram in Nigeria, Al Shabab in Somaliland, Al Qaeda in Afghanistan, the bombings in Tunisia and neighbouring countries. It is important to note that religious extremism can manifest in the adherents of all religions, and not only in Muslims, as is often thought. In its International Religious Freedom Report (2014), the United States', Department of State, Bureau of Democracy, Human Rights and Labor (2014:1-13) enumerates a long list of religiously intolerant behaviour and perpetrations on the part of individuals, organisations and governments that have affected the lives of the adherents of a wide variety of religions. These religions range from Judaism or Zionism through Shia, Sunni, Sufi, Tataric and Uighur Islam, Buddhism, Ukrainian Orthodox, Protestant and Catholic Christianity, the Baha'i and Yarsani religions, to the Mennonite religion. According to Henderson (2013) some of the 'worst terror attacks' in the United States of America were perpetrated by Christians. The list of religiously intolerant perpetrations by individuals bearing the engravings, marks or character of religious intolerance on their souls is virtually endless. How and by whom have their souls been engraved with such a character of religious intolerance?

The purpose of this article is to show how, through education, significant persons in the lives of young people such as their parents, friends, older acquaintances, mentors and teachers are able to engrave the character of their wards with an 
inclination to be either religiously tolerant or intolerant of others who are religiously (and otherwise) different from them. The focus in the discussion below is on education from a scriptural perspective. ${ }^{1}$ As a result of this focus, reference will be made only in passing to the psychological aspects involved in the inculcation of religious tolerance or intolerance in young people, and no attention can be paid to the views about religious tolerance or intolerance and education expressed in other religions.

\section{Inappropriate engravings on the soul made by education gone wrong}

There are indications that extremism and intolerance as engraving or marks on the soul are made in early youth (ed. Rieker 2004:6), especially in cases where the individual attributes and behavioural traits of a young person are susceptible to strong influences (Salaam 2013:50; also Sitzer \& Heitmeyer 2003:170-173). Studies such as those reported below furthermore show that such engraving on the souls of young people comes from outside the individual, among others from influential people, as mentioned. An analysis of the narratives of young people reveals the multifarious nature of these influences.

Some young people become radicalised after being sensitised about what is represented to them as oppression of the weak by powerful and unjust forces; they then become driven by the cause of helping the oppressed to cast off the yoke (Nawaz 2014; Potgieter 2014:29, 107-115, 122-123). Other young people succumb to the lure of influential people as a result of the normal values confusion in the minds of adolescents during the growing-up process (Kasun 2013:231-232; Nawaz 2014:x, 3, 23, 35). Others follow the guidance of powerful and charismatic spiritual leaders (Davids \& Nombembe 2015:14; Nussbaum 2012:35; Potgieter 2014:3, 5, 9, 14). The social media also play a significant role in converting young people to an attitude of extremism and intolerance (Blessing 2015: 5-11; Ebrahim 2015:1; Modjadji 2015:3; Nissen 2014; Pennington 2012:285; Potgieter 2014:99).

Young people become convinced to be either religiously tolerant or intolerant due to the impact of an assemblage of influences, particularly as far as religion and culture are concerned. Their radicalisation, leading to religious intolerance, comes about through education gone wrong, that is through indoctrination. Indoctrination can be defined as a form of anti-pedagogy that deprives the young person of

\footnotetext{
1.As educationist, I align myself with the views of co-educationist Harro van Brummelen (1994:25-26) who stated that the Bible is God's authoritative Word fo life. Scripture is God's inspired self-disclosure that calls for obedience and response. Christian believers have been called to understand God's Word of life and apply it in a responsible way. As God's written Word, the Bible provides guidelines and wisdom for answers to basic questions about the kind of world we live in and our role in it (Ps 119:105; Rm 16:25-17). If the Bible is relevant for all of life, then it is also relevant for education. The Bible has a great deal to say about our view of person relevant for education. The Bible has a great deal to say about our view of persons and their relationship to God, to each other (also in pedagogical sense), and his creation. The Bible also gives norms for nurturing children. Yet the Bible is not sourcebook for specific teaching methods and we should not use it as such (Van Brummelen 1988:ix). As Christian believers (and not professional theologians) We use the perspectives provided by the Bible for nurturing children. This explains why this article contains references to biblical perspectives without reference to the underlying hermeneutics or exegesis of such references. Space constraints also do not allow such excursions.
}

free choice about life-issues, which closes the mind of the young person to other options in life, inculcates and reinforces a single obsessional view in the young person and resultantly makes dialoguing with him or her very difficult (Potgieter 2014:176). Indoctrination takes many forms but always seems to parasitise on good, balanced and positive education.

Indoctrination is sometimes used to root the young person in the collective narrative of a fundamentalist and extreme approach to his or her religion (Kupermintz \& Salomon 2005:294; Sitzer \& Heitmeyer 2003:172; Von Hippel 2002:34). Indoctrination causes the 'miniaturisation' of the young person, i.e. it changes him or her into just a small cog in a large ideological community (Armstrong 2014:28; Davies 2006:188; Wahl 2004:17). Miniaturisation, in turn, can lead to epistemic rigidity in the young person (Nissen 2014). It also reinforces a sense of injustice about the asymmetries of power between what is perceived as the powerful and the oppressed in society (Armstrong 2014:28; Kupermintz \& Salomon 2005:298). As a result of indoctrination, the young person begins perceiving the adherents of other religions as a threat (Kupermintz \& Salomon 200:298). Indoctrinators tend to use stereotyping (Nawaz 2014:170), stigmatisation (Rieker 2004:6) and irrational fear of those who adhere to other religions (Govender 2015:14; Nawaz 2014:xx; Nussbaum 2012:236). In all of these processes, the indoctrinator exploits the normal confusion about values in the mind of the adolescent to guide the young person into forming the identity of a religious extremist, fundamentalist, a person prone to religious intolerance (Davies 2006:188-189; Nawaz 2014:xx). It can be concluded that the religious identity that the young person develops as a result of indoctrination bears the marks, engravings, encryptions or characteristics of religious intolerance. This insight is important with respect to what will be remarked below about personal integrity.

The fact that fear of others and the unknown might be the key to whether a person becomes religiously intolerant and hence runs the risk of becoming a religious extremist, fundamentalist and even a terrorist, places a heavy burden on educators involved in the shaping of young people since education covers every conceivable aspect of young people's lives. This can be demonstrated by contrasting the results of normal, successful education with the upshot of a fear- and threatdriven education (indoctrination) (see Table 1).

Although the table does not cover all the effects that education might have on the souls of young people, and unavoidably generalises and overemphasises some of the effects of education or indoctrination, it answers the question why some people acquire the defining quality or characteristic of intolerance with respect to adherents of other religions, while others do not. When the various educational processes of education go wrong (deteriorate into indoctrination), they seem to etch religious intolerance on a person's being, personality, or soul. As the mirror image of positive education, indoctrinators avail themselves of interventions typical of 
TABLE 1: Contrasting education that leads to security and tolerant behaviour with education that leads to insecurity and intolerance of others

\begin{tabular}{|c|c|}
\hline $\begin{array}{l}\text { Facet of the young person's life } \\
\text { shaped through education }\end{array}$ & Education that leads to security, safety, personal integrity \\
\hline Religious commitment & $\begin{array}{l}\text { Religiously deeply committed; accepts and respects the fact that other } \\
\text { people might be as deeply committed to their respective religions. }\end{array}$ \\
\hline Faith and belief aspect & $\begin{array}{l}\text { Educated to believe in what is regarded as the deity and other key aspects } \\
\text { of religion; belief leads to security and integrity of personality; accepts the } \\
\text { right of others to believe and have faith in their deity and other aspects of } \\
\text { their religion; prepared to allow adherents of all religions to erect faith } \\
\text { structures and places of worship. }\end{array}$ \\
\hline Ethical aspect & $\begin{array}{l}\text { Educated to be caring, loving, nurturing, to look after the interests of all } \\
\text { others, even those not belonging to the same religion; prepared to trust } \\
\text { the bona fides of others and their religions; curious about the unknown. }\end{array}$ \\
\hline Moral aspect & $\begin{array}{l}\text { Educated to form a personal value, norm and principle system; respect for } \\
\text { the fact that others might entertain different value systems based on their } \\
\text { religious and faith commitment; applies moral imagination. }\end{array}$ \\
\hline
\end{tabular}

Justice aspect Educated to act and think justly about others and their uniqueness; respect for the dignity of others; understands the various facets of social justice; attempts to restore power imbalances in society by peaceful means.

Education that leads to insecurity, perceptions of others and their religions as a threat, lack of personal integrity

Religiously deeply committed, even to the extent of an unhealthy and unbalanced commitment; suspicious of other people and their religions; respect only for the own religion.

Educated to believe in what is regarded as the deity and other key aspects of religion; deeply suspicious of the truth value of other faiths, beliefs and religions; reluctant to allow adherents of other religions to erect faith structures and places of worship.

Educated to be caring, loving, nurturing, to look after the interests of members of the own religion; prepared to act to the detriment of members of other religions; shows a deep distrust and fear of others and their religions; rejection of distrust and fear
the unknown.

Educated to form a personal value, norm and principle system; suspicious of the value and norm systems of others and their truth bases; unable or unwilling to apply moral imagination.

Educated to respect only their own interests; willing to act to the detriment of others; understands the various aspects of justice though only with respect to their self and own community; justice not necessarily meted out towards others; lack of respect of the dignity of other individuals and their religious affiliations; attempts to redress power imbalances and asymmetries by force, if necessary.

Educated to live in harmony with others however different they might be in religious terms; understands the notion of modus vivendi [peaceful coexistence].

Economic and commercial activity

Educated to live in a well-defined social and economic space, and to respect the right of members of other religious groups to have similar spaces in which to express themselves; taught to engage with all people for the sake of a free economy, commerce and trade.

Social interactivity

Educated to interact socially with all other people, irrespective of religion or faith commitment; willing to dispense social justice in all its forms to all other people and groups; trained to peacefully engage with all people.

Symbolic and historical aspect

Educated to respect the history, monuments and symbols of own religious group; accords the same respect to the history, monuments and symbols of other religious groups.

Language aspect

Educated to speak of others in a language that speaks of respect for religious differences.

Perceptions and thoughts aspect Educated to perceive and to think of all people, irrespective of religious affiliation, in respectful and positive terms.

Educated to live in harmony with members of only the own group; prepared to disrupt existent social harmony through terroristic deeds; understands the notion of modus vivendi only in so far as it means peaceful coexistence with members of the own group; other groups are seen as threats and to be feared.

Educated to live in a well-defined social and economic space; unwilling to accord the same type of space to others; prepared to destroy the economic structures of dissenters; tend to avoid trade and commerce with religious dissenters.

Educated to interact socially only with particular or selected individuals or groups; trained to be highly suspicious of other groups; tends to shun interaction with persons of different religious persuasion; willing to use force to the detriment of others and to the advantage of the own group.

Educated to respect history, monuments and symbols of the own religious group only; willing to destroy history, monuments and symbols of other groups (as recently occurred in the Ukraine and in South Africa).

Educated to speak of the believers of other religions in derogatory and insulting terms.

Educated to perceive and to think of members of other religious groups in negative terms; educated to use language that expresses fear and displays a lack of information or knowledge about others.

Educated to be fearful, suspicious, hateful and aggressive towards members of other religious groups; having thoughts of hate, retribution and aggression regarding others and their religious affiliations.

Educated to be open to all kinds of influences; to be discerning; to become a psychologically balanced person, as far as possible; positive thoughts and perceptions about others and their religious affiliations.

Physical aspect

Educated to avoid physical force against others, for whatever reason.
Educated to grow up with the notion that physical force might be necessary against members of other religious groups. education such as guidance, teaching, leading, equipping, forming and enabling young people, though in a negative sense, i.e. towards a destructive and anti-social attitude, behaviour and acts. The table shows that destructive and anti-social attitudes, behaviour and acts not only affect the religious aspect of young persons but also all their other functions as human beings. The education of a young person, hence also of the groups with which they affiliate tends to cover all the facets of being human - positively in the case of religious tolerance, and negatively in the case of religious intolerance.

Parents, teachers, spiritual leaders and other educators who have the interests of children and young people at heart cannot reconcile themselves with negative engraving of the souls of the young people in their care. As will be argued below, true educators do their utmost to engrave the souls of the young with positive influences that will shape them into good citizens, members of society that have their community's well-being and quality of life at heart.

The rest of the argument about the positive engraving on the souls of children and young people to become balanced, mature grown-ups, responsible citizens and valuable members of their societies, who eschew all forms of religious intolerance, will now unfold as follows. The following section outlines what education entails that leads to positive engravings on the souls of the young. The section thereafter explains the need for young people to form a life-map that can guide them through an increasingly religiously and culturally pluralistic social setup. It explains how persons' life-maps are rooted in their basic religious commitment and how those life-maps form part of their cultural equipment. The penultimate section explains how everything outlined in 
the preceding sections culminates in shaping an integrated personality, a person with an identity equipped with the 'right' characteristics or engravings of the soul, and hence a person with a positive history, culture and biography. A general conclusion is then drawn.

\section{Education as positive engraving on the souls of the young}

In contrast to indoctrination, true education has only one function and that is to form a mature person with religiously and socially acceptable characteristic or engravings on the soul. All right-minded parents and religious groupings wish for their children to grow up to become mature individuals that would fulfil their calling in life, be useful citizens, well socialised and able to lead a sensible life that contributes not only to their own well-being but also to that of society in general (Van Crombrugge 2006:11). Education is a process of nurturing, guiding, leading, forming, equipping, enabling, unfolding, developing, shaping and training of the innate potential of the young person so that this ideal can be realised (Nussbaum 2011:23; Van Dyk 1993:157ff.).

Successful education shapes the young persons to possess as adults integrated or organic personalities (Nolan 2009:63), to become persons who have developed life-maps that would guide them through a world of increasing religious and cultural plurality and diversity. A person with an integrated or organic personality is one who has made a conscious ideological or religious choice. Such people are able to have a careful look at themselves, their motives, their egos, their self-interests, their inner voice, and they show a need for unselfish commitment to the common good, for honesty, humility and for a spirit of unselfish service (Nolan 2009:66). Notshulwana (2011:16) concludes that integrity embodies three steps: discerning what is right and what is wrong; acting on what one has so discerned even at personal cost, and saying openly that you are acting on your understanding of right and wrong. The first criterion captures the idea of integrity as requiring a degree of moral reflectiveness. The second brings in the ideal of an integral person as steadfast, which includes the sense of keeping commitments. The third says that a person of integrity is unashamed of doing the right thing. The development of an integrated personality and hence a view of right and wrong depends to a significant extent on one's education, and on how - through education one has integrated the educational influences, including one's sense of right and wrong, as etchings on one's soul. The etchings, engravings on, the character of your soul resulting from your upbringing and education find concrete expression in your life-map (lifeview or worldview).

While a person's life-map shows the way through a world and a reality that is increasingly becoming more complex, diverse and pluralistic (Van der Walt 1999:58), it also acts as a two-way bridge between one's views and convictions about the world and reality, and the world and reality as it reveals itself to the observer. We tend to see the world in a particular way on the basis of our life-map, while on the other hand the changing world and reality around us causes us to occasionally change our views about the world and reality (Van der Walt 1999:56; Peck 2006:33). Through education and other extraneous influences (such as the social media) we receive a number of imprints or engravings in or on our souls, in the shape of routes through the world and reality printed on our life-maps. One of the engravings that have to be made on the soul of a young person, one of the routes that have to be mapped out on a person's life-map is the need to be tolerant of others of different religious persuasion, of those who differ in terms of religion, spirituality or ideology. Christians are compelled to have such tolerance engravinged on their souls, to have life-maps based on the Great Commandment in Matthew 22:37-39. The bridge metaphor furthermore suggests that it would be possible, in principle, for persons who have been educated (indoctrinated) to be religious fundamentalists, extremists or fanatics to become converted in later life to a more 'normal' and tolerant lifeview and attitude based on their observations about how 'ordinary' people actually behave in their dealings with others of different religious persuasion.

Persons with all the 'correct' socially sanctioned engravings, markings or etchings on their souls, including the engraving (characteristic) of being tolerant of adherents to other religions, can be regarded as truly cultured or refined persons. Such persons have through education been 'cultivated' to bear all the marks or engravings of socially well-adapted individuals, able to meet all the demands of modern life in a pluralistic and diverse society, and therefore also willing and able to be tolerant of those who are religiously different.

\section{Religious tolerance as appropriate engraving on the soul}

While much can be said about education in general, about the need to develop an integrated and integral personality, a lifemap and to be truly cultured, we must now restrict our attention to the matter of engraving in the souls of young people with the notion of religious tolerance. This specific facet of shaping the soul of the young pertains to a person's religious or spiritual aspect as it expresses itself in terms of a person's faith, belief, religious practice, and also in terms of one's ethical relationship with others of other religious persuasions. All of these attributes of the soul (that flow from the heart - Prov 4:23) have to be formed and shaped (engraved) into an attitude of religious tolerance. The following are the key perspectives of religious tolerance that have to be developed and shaped through education.

Every young person should be educated (engraved in or on their soul) to understand that others of different religious persuasion are entitled to the freedom to follow their conscience and to act according to their own firmly held religious beliefs (Furedi 2012:30-31, 37; Nussbaum 2012:241). Everyone possesses the right to express oneself freely (Joe 2011:6) in one's particular circumstances. The differences that emerge as a result of this recognition should be respected (Potgieter, Van der Walt \& Wolhuter 2014:3). Nussbaum 
(2012:97) and Potgieter (2015:55) liken the attitude of a religiously tolerant person with that of a gracious hostess: she sees others as her equals, respects them and does everything in her power to accommodate them. She remains interested in them (Nussbaum 2012:241) and shows positive appreciation of the differences among people, even of conflicting views (Furedi 2012:37).

While displaying this attitude of tolerance, educators should demonstrate that they understand the difference between 'acceptable tolerance' and 'unacceptable tolerance'. The former is exemplified in the life and work of Christ (Mt 19:13-14; Mk 10:13-16; Lk 18:15-17) and of Paul (Phlp 1:17-18). The latter refers to tolerance of evil and wrong (Hab 1:13), wickedness ( $\operatorname{Rv} 2: 2)$, serious doctrinal error (Gl 2:4; 2 Th 2:1-3; 1 Tm 6:3-5, 20-21; 2 Tm 4:3-4; 2 Pt 2:1), sexual sin (1 Cor 5:1-5; 6:18-20; Rv 2:14) and idolatry (1 Cor 10:7; 1 Jn 5:21; Manser 2009).

Young people have to be educated to understand that religious tolerance makes sense only in a context of religious or ideological differences (Saulius 2013:50). Recognition of difference is tantamount to recognition of others as full, equal and equivalent members of society (Galeotti 2014:9). This does not mean that people have total freedom to behave as they wish (Boersma 2012); everyone remains bound to the basic rules and norms of society. Everyone also has the freedom to be critical of other peoples' views, attitudes and behaviour, and to discriminate between what is right and wrong in the behaviour of others (Furedi 2012:31-37). While one might question or reject the behaviour of another person, that person may never be rejected as a person. All people form part of a community and have to be accepted as such. Understanding of others also depends on understanding the contextual factors that seem to determine or influence the other's behaviour. Such understanding is necessary for friendly coexistence (Nussbaum 2012:174, 210).

Young people should furthermore be educated to grasp the idea that religious tolerance also presupposes respect for others and their religious peculiarities, practices and beliefs, and for their rights and dignity as human beings (Galeotti 2014:8). They are entitled to this respect not only because they are members of a modern liberal and democratic society but because they are people, created with human dignity. They are entitled to equal treatment, fairness and social justice. Without this recognition, peaceful coexistence with others will be impossible (Furedi 2012:30-31, 37). Peaceful coexistence is also not possible if it depended on the likes and dislikes of individuals; the necessary contextual factors promoting coexistence should be present (Potgieter 2015:55). Peaceful coexistence is furthermore not possible if society is being dominated by the whims of a majority (Galeotti 2014:6). In the final analysis, religious tolerance is the recognition of the freedom and right of others to follow their conscience and to search for the truth as they see it. Tolerance also presupposes a process of engagement with the moral or ethical choices that one is confronted with in the attitudes and behaviours of others (Furedi 2012:32). This engagement has become more of a challenge in recent years because of ever increasing social, religious and cultural pluralism (Galeotti 2014:10).

Finally, young people have to be formed to understand that religious tolerance presupposes compassion with others and their religious differences. This is in line with the biblical injunction of Matthew 22:37-39. As mentioned, religious tolerance seems to have an ethical or moral aspect: one is constantly faced with the issue of whether one is prepared to treat the other and their views and attitudes as one would treat one's own. The only way to effectively deal with this challenge is to place oneself in the shoes of the other through the process of moral imagination or 'critical interpathy'. Only after having done this can one understand the motives behind another person's attitude and behaviour (Nussbaum 2012:21, 28) and decide about the most appropriate response to them (Bucher \& Manning 2010:160-163; Skiba \& Peterson 1999:9-10). Moral imagination will help to understand what the burden of other's religion is to them and how they look at reality (their life-maps). It also helps one to refrain from summary rejection or condemnation of others and their views and attitudes (Nussbaum 2012:96). Refusal to interact or engage with others with different religious views can be construed as a lack of understanding and empathy, and hence as intolerant behaviour (Nussbaum 2001:417). Religious tolerance depends on the creation of an equivalent space for all to meet the demands of their consciences in equal measure, irrespective of whether consensus exists about what is being thought and done in that space. Recognition of such equivalent space results in a pluralistic society in which every member reflects in participatory manner about all the others and their uniqueness, without condemnation or placing obstacles in their way (Nussbaum 2012:144).

\section{Religiously tolerant versus intolerant individuals: Differences in identity, culture, history and biography}

It can be concluded on the basis of the argument so far that persons whose education has somehow gone wrong and have resultantly been coerced or deceived into following a religiously radical, extremist, fundamentalist, even terroristic, religiously intolerant course in life cannot be regarded as persons with integrated, balanced personalities, and approach to life and to people with other religious persuasions. While the persons with religiously extremist or fundamentalist views of reality and of other people and their religious idiosyncrasies might be said to have been educated (more precisely, indoctrinated) and to have life-maps, their basic orientation to the world and to others who differ from them on religious grounds cause them to be religiously intolerant. They do not display any of the characteristics (i.e. engravings on the soul) of people who are truly tolerant of others and their religious differences. In brief, they bear the identity, culture, history and biography of religiously intolerant people. 
In contrast, individuals who received a balanced education that kept open their options to choose life-altering alternatives, that provided the freedom to choose according to their conscience, and have been guided, trained, formed and equipped (educated) to become integrated personalities can be said to possess the identity, culture, history and biography of truly tolerant individuals. They tend to display the unique identifying characteristics (engravings, markings on their soul) of persons who are tolerant of others and their religious orientations. They have a history of being tolerant: the record of their past actions and engagement with others attests to their religious tolerance. They furthermore display the cultural background of tolerant persons, i.e. the total of their inherited ideas, beliefs, values and knowledge which constitute the shared basis of their tolerant social action, attest to the fact that they are religiously tolerant of others in a pluralistic society and culture. Finally, their biographies, i.e. the accounts of their lives, attest to the same effect.

The biographies of people are important to researchers interested in the state of religious tolerance in a society. A questionnaire to establish the extent to which a person is religiously tolerant of others of different religious persuasion in a pluralistic society will necessarily contain a number of biographical items, that is items about the identity, history, culture and life-story or narrative of the respondents. Evaluation of responses to such items in the questionnaire will enable the researcher to establish whether a respondent's religious upbringing has been of a kind that will promote religious tolerance or whether it has somehow gone wrong and hence led to religiously intolerant behaviour in a respondent.

\section{Conclusion}

Modern, increasingly pluralistic and religiously diverse societies require individuals and groups to demonstrate religiously tolerant attitudes and behaviour for the sake of peaceful coexistence. Unfortunately many young people are being led astray by influential people in their lives through indoctrination and the resourceful use of social media. The key to peaceful coexistence among individuals and groups of widely different religious persuasion is religious tolerance. This comprises a characteristic or 'engraving on the soul' that does not come naturally but has to be brought home to a young person through education in the most positive sense of the word, i.e. education that allows young persons the freedom of conscience to decide for themselves which options to follow for the future, which life-maps to develop, and hence which type of identity, history, culture and biography to develop.

\section{Acknowledgements Competing interests}

The author declares that he has no financial or personal relationships which may have inappropriately influenced him in writing this article.

\section{References}

Armstrong, K., 2014, 'The deep roots of Islamic state Wahabism - And how Saud Arabia exported the main source of global terrorism', New Statesman 143(5237), 24-31.

Blessing, M., 2015, 'De mystieke lokroep van IS', Trouw: Letter en Geest, 6 June, pp. 5-11. Boersma, P., 2012, Personal communication, Besturenraad, Gouda.

Bucher, K.T. \& Manning, M.L., 2010, 'Challenges and suggestions for safe schools', The Clearing House: A Journal of Educational Strategies, Issues and Ideas 76(3), 160-164, viewed 30 November 2014, from http://tandfonline.com/loi/vtch20.

Davids, N. \& Nombembe, P., 2015, 'PE man takes family to join Islamic State', Sunday Times, 19 April, p. 14.

Davies, L., 2006, 'Educating against extremism: Towards a critical politicisation of young people', International Review of Education 55(2-3), 183-203.

Ebrahim, S., 2015, 'Teen saved from Islamic State', The Star, 7 April, p. 1.

Furedi, F., 2012, 'On tolerance', Policy 28(2), 30-37.

Galeotti, A.E., 2014, 'The range of toleration: From toleration as recognition back to disrespectful tolerance', Philosophy and Social Criticism, viewed 30 November 2014, from http://psc.sagepub.com/content/early/2014/11/20/0191453714559424

Govender, S., 2015, 'Comic in "regular" Muslim campaign', Sunday Times, 19 April, p. 14.

Harper, D., 2001-2015, Online Etymology Dictionary, viewed 16 June 2015, from www.etymonline.com/index.php?term=soul

Henderson, A., 2013, 10 worst terror attacks by extreme Christians and far-right white men, viewed 14 January 2016, from http://www.alternet.org/tea-party-andright/10-worst-terror-attacks-extreme-christians-and-far-right-white-men

Joe, D., 2011, Review of F. Furedi's "On tolerance: A defence of moral independence", Continuum Publishing, viewed 2 July 2014, from http://www.manchestersalon. org.uk/on-tolerance-frank-furedi.pdf

Kasun, G.S., 2013, 'We are not terrorists', but more likely transnationals: Reframing understandings about immigrants in light of the Boston marathon bombings', Multicultural Perspectives 15(4), 227-233. http://dx.doi.org/10.1080/15210960. 2013.844611

Kupermintz, H. \& Salomon, G., 2005, 'Lessons to be learned from research on peace education in the context of intra ctable conflict', Theory into Practice 44(4), 293-302. http://dx.doi.org/10.1207/s15430421tip4404_3

Manser, M.H., 2009, Dictionary of bible themes: The accessible and comprehensive tool for topical studies, Manser, London.

Modjadji, N., 2015, 'Girl, 15, pulled from “IS flight”', The Citizen, 7 April, p. 3.

Nawaz, Z., 2014, Laughing all the way to the mosque, Virago Press, London.

Nissen, L.S., 2014, 'Inside ISIS: The making of a radical', viewed 4 May 2014, from Narrative.ly/stories/inside-isis-the-making-of-a-radical/

Nolan, A., 2009, 'The spiritual life of the intellectual', in W. Gumede \& L. Dikeni (eds.), South African democracy and the retreat of intellectuals, pp. 57-66, Jacana, Auckland Park.

Notshulwana, V., 2011, 'Integrity and what it means in age of entitlement', The Herald, 17 February, p. 16.

Nussbaum, M.C., 2001, Upheavals of thought: The intelligence of emotions, Cambridge University Press, Cambridge.

Nussbaum, M.C., 2011, Creating capabilities, The Belknap Press, Cambridge.

Nussbaum, M.C., 2012, The new religious intolerance, The Belknap Press, Cambridge.

Online Etymological Dictionary, 2015, 'Character', viewed 16 June 2015, from http:// www.etymonline.com

Peck, M.S., 2006, The road less travelled, Random House, London.

Pennington, B.K., 2012, Teaching religion and violence, Oxford University Press, Oxford.

Potgieter, De W., 2014, Black widow white widow, Penguin Books, Johannesburg.

Potgieter, F.J., 2015, 'Beyond tolerance: Educating for religious respect and hospitality in pedagogic-multilogical sanctuaries', in N. Popov (ed.), Quality, social justice and accountability in education worldwide, pp. 53-59, Bulgarian Comparative Education Society, Sofia. (BCES Conference Books 13(1)).

Potgieter, F.J., Van der Walt, J.L. \& Wolhuter, C.C., 2014, 'Towards understanding (religious) (in)tolerance in education', HTS Teologiese Studies/Theological Studies 70(3), 1-8. http://dx.doi.org/10.4102/hts.v70i3.1977, Ed.

Rieker, P. (ed.), 2004, 'Einleitung', in P. Rieker (ed.), Der früe Vogel vängt den Wurm! Soziales Lernen und Prävention von Rechtsextremismus und Fremdfeindlichkeit in Kindergarten und Grundschule, pp. 1-5, Deutsches Jugendinstitut Arbeitstelle, Halle.

Salaam, A., 2013, 'The psychological make-up of Mohammed Yusuf', in I. Mantsikos (ed.), Boko Haram: Anatomy of crisis, pp. 46-52, University of Surrey, Bristol.

Saulius, T., 2013, 'What is "tolerance" and "tolerance education"?', Philosophical Perspectives (Ugdymas. Kuno Kultura, Sportas, Socialiniai Mokslai) 89(2), 49-56.

Schultz, C., 2015, 'Baker's evangelical dictionary of biblical theology', viewed 16 June 2015, from http://www. Biblestudytools.com/dictionaries/bakers-evangelicaldictionary/soul.html 
Simpson, D.P., 1968, Cassell's new Latin-English English-Latin Dictionary, Cassell, London.

Sinclair, J.M., 1999, Collins concise dictionary, HarperCollins, Glasgow.

Sitzer, P. \& Heitmeyer, W., 2003, 'Right-wing extremist violence among adolescents in Germany', New Directions for Youth Development 2008(119), 169-185. http:// dx.doi.org/10.1002/yd.279

Skiba, R. \& Peterson, R., 1999, 'The dark side of zero tolerance: Can punishment lead to safe schools?' Phi Delta Kappa International, viewed 23 March 2014, from http://www.pdkintl.org/kappan/kski9901.htm/

Thurman, C., 1999, The lies we believe, Thomas Nelson, Nashville, TN.

Towner, P.H., 2015, 'Baker's evangelical dictionary of biblical theology', viewed 16 June 2015 , from www. Biblestudytools.com/dictionaries/bakers-evangelical-dictionary/ mind-reason.html

United States, Department of State, Bureau of Democracy, Human Rights and Labor 2014, International Freedom Report for 2014: Executive summary, Washington, DC.

Van Brummelen, H.W., 1988, Walking with God in the classroom: Christian approaches to learning and teaching, Welch Publishing, Burlington.
Van Brummelen, H.W., 1994, Steppingstones to curriculum: A biblical path, Alta Vista College Press, Seattle, WA.

Van Crombrugge, H., 2006, Denken over opvoeden, Garant, Apeldoorn.

Van der Walt, B.J., 1999, Visie op die werklikheid, (Instituut vir Reformatoriese Studie (IRS), Potchefstroom

Van Dyk, J., 1993, 'The practice of teaching Christianly', in S. Fowler, H.W. van Brummelen \& J. van Dyk (eds.), Christian schooling: Education for freedom, pp. 155-168, Instituut vir Reformatoriese Studie (IRS), Potchefstroom.

Von Hippel, K., 2002, 'The roots of terrorism: Probing the myths', The Political Quarterly 73(Suppl. S1), 25-39. http://dx.doi.org/10.1111/1467-923X.73.s1.4

Wahl, K., 2004, 'Gibt es mögliche Vorlaüfer für Rechtsextremismus und Fremdfeindlichkeit, die sich bereits im Kindergarten- und Grundschulalter zeigen?', in P. Rieker (ed.), Der früe Vogel vängt den Wurm! Soziales Lernen und Prävention von Rechtsextremismus und Fremdfeindlichkeit in Kindergarten und Grundschule, pp. 9-19, Deutsches Jugendinstitut Arbeitstelle, Halle.

Waltke, B.K., 2015, 'Baker's evangelical dictionary of biblical theology', viewed 16 June 2015, from http://www.Biblestudytools.com/dictionaries/bakers-evangelicaldictionary/heart.html 